\title{
Nutritional and technological aspects of vegetable oils that stand out for the prevalence of medium-chain triacylglycerides: A review
}

\author{
Aspectos nutricionais e tecnológicos de óleos vegetais com predominãncia de triacilglicerois de \\ cadeia média: Uma revisão \\ Aspectos nutricionales y tecnológicos de los aceites vegetales con un contenido predominante de \\ triglicéridos de cadena media: Una revisión
}

\begin{abstract}
The nature of the fatty acid presented in each type of vegetable oil will determine the oil's characteristic. The purpose of this review is to describe the medium chain fatty acids present in vegetable oils absorption mechanism and their benefits for human body, combined with technological advantages in the preparation of food formulations. Highlighting how the source of the raw material and the extraction method interfere with the concentration of fatty acids present in the oils. It is a review of narrative literature, which used as a theoretical framework recent scientific articles in the English language. Oils derived from coconut, palm kernel, and babassu, for example, have a solid or semi-solid characteristic at room temperature. This happens due to the presence of saturated fatty acids with mediumlength carbon chains, that is from 6 to 12 carbons. Although medium-chain fatty acids are saturated, they present characteristics that are different from other long-chain saturated fatty acids. They are quickly digested by the body, which favors the absorption and the using of these nutrients, leading an impact on diseases' control, such as obesity, diabetes and hypertension. In addition, due to their chemical structure, medium chain fatty acids can be used in the food industry as a substitute for animal fat, combining their nutritional benefits with technological advantage, being used in food preparations to impact texture, flavor, stabilize emulsions, and improve the rheological characteristics of the product.
\end{abstract}

Keywords: Obesity; Coconut oil; Kernel palm oil; Babassu oil; Medium-chain fatty acid.

\section{Resumo}

A natureza do ácido graxo presente em cada tipo de óleo vegetal, irá determinar a característica desse óleo. O objetivo do estudo foi descrever o mecanismo de absorção dos ácidos graxos de cadeia média presentes em óleos vegetais e seus benefícios ao organismo humano, aliado aos benefícios tecnológicos no preparo de formulações alimentícias. Destacando como a fonte da matéria-prima e o método de extração interferem na concentração dos ácidos graxos presentes nos óleos. Trata-se de uma revisão de literatura narrativa, que utilizou como referencial teórico artigos 
científicos recentes na língua inglesa. Óleos derivados do coco, palmiste e babaçu por exemplo, apresentam característica de sólido ou semissólido em temperatura ambiente. Isso acontece devido à presença predominante de ácidos graxos saturados com cadeias carbônicas de comprimento médio, ou seja, de 6 a 12 carbonos. Os ácidos graxos de cadeia média apresentam características distintas dos outros ácidos graxos saturados de cadeia longa, são rapidamente digeridos pelo organismo o que favorece a absorção e utilização desses nutrientes, exercendo impacto no controle de doenças como obesidade, diabetes e hipertensão. Além disso, devido a sua estrutura química os ácidos graxos de cadeia média podem ser utilizados na indústria de alimentos como substituto de gordura animal, aliando seus benefícios nutricionais aos benefícios tecnológicos, sendo empregado em preparações alimentícias para conferir textura, sabor, estabilizar emulsões e melhorar as características reológicas do produto.

Palavras-chave: Obesidade; Óleo de coco; Óleo de palmiste; Óleo de babaçu; Ácido graxo de cadeia média.

\section{Resumen}

La naturaleza de los ácidos grasos presentes en cada tipo de aceite vegetal determina sus propiedades. El propósito de esta revisión es describir el mecanismo de absorción de los ácidos grasos de cadena media presentes en los aceites vegetales y sus beneficios para el cuerpo humano, además de los beneficios tecnológicos en la preparación de formulaciones alimentarias. Destacando la manera en que la fuente de la materia prima y el método de extracción interfieren con la concentración de ácidos grasos presentes en los aceites. Se trata de una revisión de la literatura narrativa, que utilizó como marco teórico artículos científicos recientes en lengua inglesa. Los aceites derivados de coco, palmiste y babasú, por ejemplo, son sólidos o semisólidos a temperatura ambiente. Lo anterior se puede deber a la predominar presencia de ácidos grasos saturados de longitud media, es decir de 6 a 12 carbonos. Aunque los ácidos grasos de cadena media son saturados, presentan características (propiedades) diferentes a otros ácidos grasos saturados de cadena más larga, pues son rápidamente absorbidos y digeridos en el organismo, lo que favorece el aprovechamiento de estos nutrientes, influyendo en el control de enfermedades como la obesidad, diabetes e hipertensión. Adicionalmente, por su estructura química, los ácidos grasos de cadena media pueden ser utilizados en la industria alimentaria como sustitutos de grasa animal, combinando sus beneficios nutricionales con beneficios tecnológicos al ser incluidos en preparaciones alimentarias con el fin de impartir textura, sabor, estabilizar emulsiones y mejorar las características reológicas del producto.

Palabras clave: Obesidad; Aceite de coco; Aceite de palmiste; Aceite de babasú; Ácidos grasos de cadena media.

\section{Introduction}

Vegetable oils can be extracted from vegetable raw materials such as grains, seeds, cereals, fruits and other food types (Costa et al., 2019). The main component of oils are lipids that account for different functions in the body, such as providing energy, contributing to hormone formation and producing satiety; in addition, they are of great importance for the food industry since they can change the flavour and texture of processed food. Lipids found in oils are mostly composed of both triacylglycerols and small amounts of mono and diacylglycerols (Kumar \& Krishna, 2015).

The physical, chemical and nutritional properties of oils depend on the nature of fatty acids found in them, which, in their turn, are influenced by the source of oil's raw material. The raw material for oils can be influenced by the variety and maturation stage of the fruits, climate where it was cultivated other factors capable of interfering with the features of the vegetable raw material (Maruyama et al.2014).

Each fatty acid has a different feature, i.e., number of carbons in the chain, degree of saturation, which determines the chemical behaviour of this oil and its stability in the face of changes in temperature, storage and other factors (Dhamodharan \& Bakthavatsalam, 2020).

Among saturated fatty acids, we can highlight those of medium-chain, which are found at high concentration in the composition of some vegetable oils such as coconut, babassu and kernel palm oil. The presence of medium chain fatty acids has straight impact on the absorption of these oils by the body, a fact that means several benefits to consumers' health (Figure 1). In addition to the nutritional aspects, the chemical structure of these fatty acids presents technological features such as low melting point, which cause these oils to solidify at temperatures below $25^{\circ} \mathrm{C}$ and to return to the liquid state when the room temperature increases - this process does not make these oils lose any technological or nutritional property(Kumar \& Krishna, 2015) (Figure 1).This phenomenon results from the prevalence of medium-chain fatty acids( MCFA) in the composition of 
these oils (Jeyarani et al., 2009).

The aim of the present review is to address vegetable oils that have high concentrations of medium-chain fatty acids (MCAF) in their composition, the features of these fatty acids and how they influence the physical-chemical properties of oils, as well as their nutritional impact on and health benefits to consumers.

Figure 1: Overview on the technological and nutritional features of medium-chain fatty acids extracted from vegetable oils.

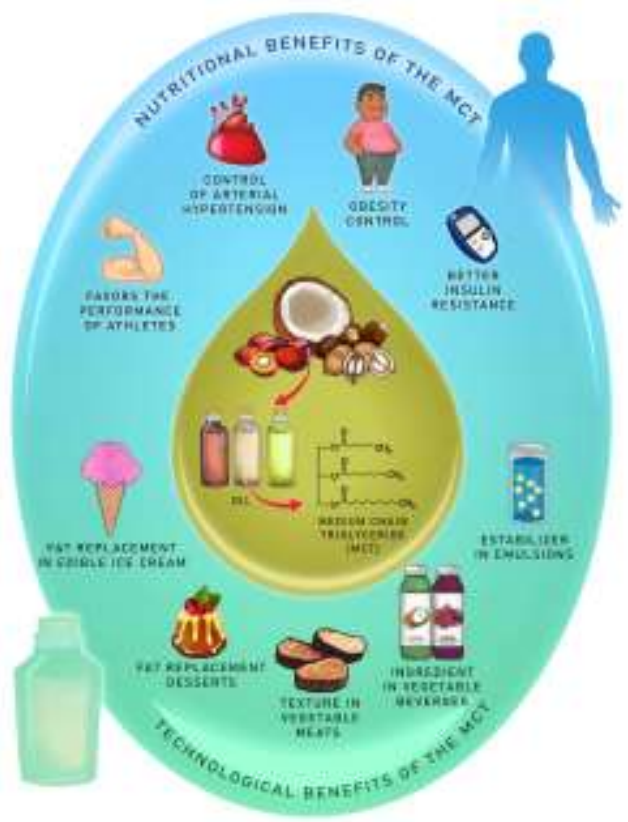

Source: Authors.

Figure 1 presents a graphic summary of all issues covered in the review. The figure illustrates the main sources of raw materials used for oil extraction with medium-chain fatty acids (MCFAs) predominance, highlighting the nutritional and technological benefits associated with MCFAs use.

\section{Methodology}

A narrative review was carried out (Sant'Anna Ramos Vosgerau \& Paulin Romanowski, 2014), through bibliographic research in different indexing bases, on topics related to the nutritional and technological properties of oils with predomin ance of medium chain fatty acids. In the search for scientific articles, the keywords "vegetable oils", "metabolic syndrome", "fatty acid nutrition and metabolism", "functional fatty acids", "medium chain fatty acid rheology" and "technological properties" were used of medium chain fatty acids".

In order to obtain reliable information on the topic, only scientific articles were searched in electronic databases such as: Scopus, Scielo, Science Direct, Web of Science and Wiley Online Library. The criteria adopted for the selection of articles included publications in the English language, preferably between the years 2015 to 2021, relevant and recent research in the nutritional and technological area on the use of medium-chain fatty acids.

\section{Results and Discussion}

\subsection{General aspects}

Vegetable oils consist of triacylglycerides extracted from plant that present glycerol molecules linked to three fatty 
acid molecules (Figure 2). Some oils, such as coconut, kernel palm and babassu oil, are mainly composed of medium-chain triglycerides such as caproic acid (C6:0) caprylic acid (C8:0), capric acid (C10:0) and lauric acid (C12:0), which are saturated fatty acids presenting carbon chains ranging from six to twelve carbons (Figure 2) (Norizzah et al., 2018).

Figure 2: Chemical structure of medium-chain fatty acids (A). Chemical structure of a medium-chain triacylglycerol (B).

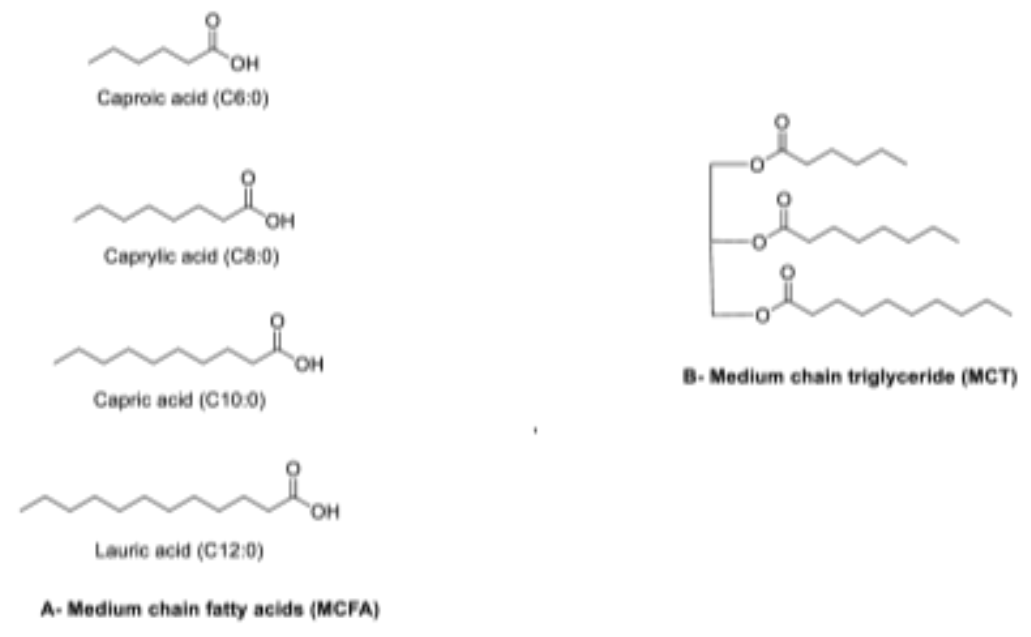

Source: Authors.

Figure 2 shows the structural formula of medium-chain fatty acids, followed by the structure of a triacylglycerol composed of medium-chain fatty acids. Fatty acid structure influences directly its solubility, melting point, absorption, and other functions. Medium-chain fatty acids have low water solubility, which is a factor related to the presence of a hydrocarbon chain, increase in acyl chain and to less double bonds. It is also associated with the presence of the carboxylic acid group, which is polar and ionized at neutral pH (Ratnayake et al., 2001).

The melting point is also influenced by the length and degree of hydrocarbon chain unsaturation. Saturated fatty acids presenting from 12: 0 to 24 : 0 carbons have wax consistency at room temperature $\left(25^{\circ} \mathrm{C}\right.$ ), whereas unsaturated fatty acids (at the same length) are oily liquids. Coconut oil has melting point close to $22.3{ }^{\circ} \mathrm{C}$ (Dhamodharan \& Bakthavatsalam, 2020), Kernel palm oil presents melting point at approximately $28.2{ }^{\circ} \mathrm{C}$ and babassu oil has melting point ranging from $24{ }^{\circ} \mathrm{C}$ to $26^{\circ} \mathrm{C}$. Soybean oil, which is composed of long chain unsaturated fatty acids, has melting point of $-20{ }^{\circ} \mathrm{C}$. This difference in melting points results from different fatty acid-molecule packaging degrees (Norizzah et al., 2018).

Carbon chain packaging is possible due to chain flexibility. Completely saturated compounds account for great hydrocarbon chain flexibility as rotation of the hydrocarbons is free around each carbon-carbon bond. The linear conformation is the most stable one, and it minimizes the steric impedance of neighbouring atoms. These molecules can group into almost crystalline arrangements - atoms along their entire length are at Van der Waals interaction with atoms of neighbouring molecules.

The double cis bond forces the hydrocarbon chain to fold in unsaturated fatty acids Fatty acids with one or more of these folds cannot clump as tightly as fully saturated fatty acids, fact that makes interactions between them weaker. Since less thermal energy is needed to clutter these poorly ordered arrangements of unsaturated fatty acids, they have considerably lower melting points than saturated fatty acids presenting the same chain length (Heil et al., 2019). 


\subsubsection{Extraction method}

Vegetable oil is extracted through different ways, the main extractions are artisanal, mechanical and made with solvent. Based on the artisanal extraction method, the fruit pulp is subjected to intensive cooking in container filled with water. After boiling the mixture, the supernatant oil is separated from the aqueous part. Then, the oil is left to dry over low heat until it loses opacity, the oil is filtered. The artisanal method has some drawbacks, such as low yield, product with opaque aspect and high humidity. Artisanal coconut oil must be centrifuged to allow better oil phase separation and waste extraction in order to avoid the oxidation process within few days (De Pinho \& Souza, 2018).

Mechanical extraction can be carried out by using the pressing technique, without solvents; thus, the obtained product maintains its natural properties. However, as the result from its lower efficiency in removing oil from the fruit or seed, this extraction method can be combined to solvent extraction in order to increase yield. Press extraction does not generate oil and cake heating, since it only requires a press and an extractor cylinder (Bhatnagar et al., 2009; De Pinho \& Souza, 2018).

Solvent extraction consists of putting an organic solvent in direct contact with the plant matrix. The oil derives from the evaporation of the solvent used in the liquid phase. This methodology is recommended for very unstable oils that do not handle temperature increase. Hexane, benzene, methanol, ethanol, propanol, acetone, pentane and several chlorinated solvents are the organic solvents mostly used in this process for oil extraction purposes. The difficulty in removing all residual solvent and non-volatile compounds that remain in the oil after extraction is one of the negative effects of using organic solvents (Nik Norulaini et al., 2009; Santos et al., 2013).

Virgin coconut oil, which is extracted from fresh coconut pulp. Coconut oil extraction process does not use heat treatment or food preservatives. It can also be called cold extraction, as the oil does not reach temperatures higher than $40{ }^{\circ} \mathrm{C}$. Conut milk is left to stand for $20-24 \mathrm{~h}$, under favourable conditions (35-40 ${ }^{\circ} \mathrm{C}, 75 \%$ relative humidity). Autochthonous lactic acid bacteria, which have the ability to break protein bonds, act in the coconut milk mix by causing the separation of virgin coconut oil. The separated oil is filtered through sterile paper filter placed in a large funnel. Refined and deodorized coconut oil derives from the extraction of dehydrated copra oil - this process is followed by alkali refining, bleaching and deodorization (Kumar \& Krishna, 2015).

Extraction can still be done by using the supercritical fluid method. Carbon dioxide is the most used solvent, mainly by the food industry, as it is not toxic, not combustible, available at high purity rates and at low cost, has low critical temperature $\left(31^{\circ} \mathrm{C}\right)$ and critical pressure (74 bars) 'which are advantages when it comes to the required energy and to the conservation of thermolabile substances' has low boiling point, does not leave solvent waste in the extracted material and accounts for good extraction yield. When this method is used to purify edible oils, it presents high solvation power and does not have its properties changed (Nik Norulaini et al., 2009).

In Table 1, it is possible to observe that fatty acids are present in vegetable oils and also products of animal origin, in lower concentrations although. The vegetal source influences fatty acids composition and determines the physical characteristics of oil, for example, solidification temperature. The fatty acids concentrations in the oils do not present sudden variations when they are subjected to different extraction methods; however, the adopted method can influence the phytochemical compounds found in plants, which are transferred to the oil and can be lost after extraction (Srivastava et al., 2016). These compounds can also influence oil solubility depending on the applied temperature and pressure (Soares et al., 2007). 
Table 1: Composition of fatty acids from different food sources.

\begin{tabular}{|c|c|c|c|c|c|c|c|c|c|c|c|}
\hline $\begin{array}{l}\text { Food } \\
\text { Source }\end{array}$ & $\begin{array}{c}\text { Extraction } \\
\text { method }\end{array}$ & C6:0\% & $\mathrm{C8:0} \%$ & C10:0 \% & C12:0\% & C14:0 \% & C16:0 \% & C18:0\% & C18:1\% & C18:2 \% & Reference \\
\hline \multirow[t]{2}{*}{ Coconut oil } & solvent & 0.35 & 7.87 & 6.07 & 49.55 & 17.03 & 8.02 & 2.71 & 7.01 & 1.39 & Srivastava et al., 2016 \\
\hline & & 48.03 & 6.27 & 7.64 & 0.64 & 16.23 & 8.40 & 3.46 & 5.80 & 0.90 & Marina et al., 2009 \\
\hline \multirow[t]{2}{*}{ Coconut oil } & Virgin & 48.08 & 6.48 & 6.01 & - & 17.72 & 7.79 & 6.94 & 0.85 & 1.61 & Zicker et al., 2019 \\
\hline & & 50.00 & 5.55 & 7.10 & 0.45 & 18.1 & 7.05 & 2.42 & 7.26 & 1.66 & Srivastava et al., 2016 \\
\hline \multirow[t]{2}{*}{ Coconut oil } & Refined & 47.42 & 6.53 & 8.24 & 0.63 & 18.26 & 9.33 & 2.68 & 5.25 & 1.57 & Marina et al., 2009 \\
\hline & & - & 7.24 & 5.25 & 50.90 & 21.38 & 9.22 & 0.38 & 4.81 & 0.81 & kumar \& krishna 2015 \\
\hline Coconut oil & $\begin{array}{c}\text { Supercritical } \\
\text { fluid }\end{array}$ & $42-47$ & $8-10$ & $10-12$ & - & $21-23$ & $7-9$ & $1-2$ & $3-5$ & $0.5-1.5$ & Norulaine et al., 2009 \\
\hline Babassu oil & Cold Press & 42.79 & 5.21 & 4.77 & 0.27 & 14.11 & 8.85 & 3.57 & 17.48 & 2.88 & Ferrari \& Soler 2015 \\
\hline \multirow[t]{3}{*}{ Babassu oil } & Solvent & 48.93 & 7.99 & 4.54 & - & 15.64 & 7.46 & 1.65 & 10.55 & 3.24 & Santos et al., 2013 \\
\hline & extraction & 47.42 & 6.46 & 8.06 & - & 15.47 & 7.60 & 2.81 & 10.28 & 1.90 & D’Anton et al., 2011 \\
\hline & & - & - & 4.1 & 36.1 & 19.4 & 12.3 & 5.8 & 19.4 & 2.8 & Oliveira et al., 2019 \\
\hline \multirow{4}{*}{$\begin{array}{l}\text { Kernel } \\
\text { palm oil }\end{array}$} & Solvent & 0.32 & 3.24 & 3.6 & 47.73 & 15.91 & 8.25 & 2.45 & 15.18 & 3.22 & Kiliç \& Özer.,2019 \\
\hline & extraction & 0.20 & 3.13 & 3.18 & 45.51 & 15.64 & 9.48 & 2.55 & 16.90 & 2.64 & Rodrigues, 2010 \\
\hline & & - & 4.45 & - & 49.1 & 17.00 & 10.0 & 2.30 & 11.00 & 1.60 & Halim et al., 2019 \\
\hline & & - & 3.01 & 3.06 & 47.85 & 17.25 & 10.31 & 2.63 & 14.43 & 1.19 & Costa et al.,2019 \\
\hline
\end{tabular}


Research, Society and Development, v. 10, n. 7, e43710716667, 2021

(CC BY 4.0) | ISSN 2525-3409 | DOI: http://dx.doi.org/10.33448/rsd-v10i7.16667

\begin{tabular}{|c|c|c|c|c|c|c|c|c|c|c|c|}
\hline $\begin{array}{c}\text { Kernel } \\
\text { palm oil }\end{array}$ & $\begin{array}{c}\text { Supercritical } \\
\text { fluid }\end{array}$ & - & $2.33-4.34$ & $2.56-4.37$ & $39.4-45.5$ & $15.9-17.25$ & $9.44-10.31$ & $1.14-3.35$ & $17.9-24.3$ & $0.9-4.36$ & Costa et al. 2019 \\
\hline $\begin{array}{c}\text { Kernel } \\
\text { palm oil }\end{array}$ & $\begin{array}{c}\text { Inter } \\
\text { esterified }\end{array}$ & 0.17 & 7.06 & 7.97 & 39.97 & 12.46 & 7.52 & 1.31 & 13.84 & 8.17 & Kiliç \& özer, 2019 \\
\hline Cow milk & - & 0.92 & 0.62 & 1.47 & 1.71 & 6.44 & 29.13 & 9.13 & 20.89 & 1.78 & Rennó et al., 2013 \\
\hline $\begin{array}{c}\text { Human } \\
\text { milk }\end{array}$ & - & - & $0.17-0.22$ & $1.46-2.00$ & 4.24- 5.86 & $4.91-6.80$ & $18.60-22.59$ & $5.77-6.25$ & - & - & Yuhas et al., 2006 \\
\hline $\begin{array}{l}\text { Ghee } \\
\text { Buffalo }\end{array}$ & - & 1.02 & 0.47 & 0.97 & 1.55 & 9.64 & 33.13 & 13.07 & 22.49 & 0.67 & Ali et al., 2020 \\
\hline $\begin{array}{l}\text { Ghee } \\
\text { Bovine }\end{array}$ & - & 1.01 & 0.61 & 1.37 & 1.79 & 7.89 & 29.76 & 13.18 & 28.76 & 0.62 & Ali et al., 2020 \\
\hline $\begin{array}{l}\text { Anhydrous } \\
\text { fat milk }\end{array}$ & - & 1.76 & 1.28 & 2.91 & 4.89 & 13.00 & 35.20 & 10.24 & - & 1.51 & Neves et al.,2020 \\
\hline
\end{tabular}

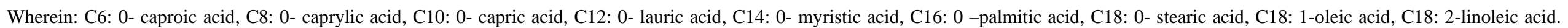
Source: Authors. 
In addition to the extraction method, the variety of the raw material and the place of origin can influence the characteristics of these oils. Ferreira et al. (2019) and Kumar \& Krishna (2015) evaluated the lipid profile of different varieties of coconut (Cocos nucifera $L$.) And observed that the composition of fatty acids in the triacylglycerol chains was not the same for all varieties. These variations in the concentration of fatty acids can also be seen in Table 1 .

The composition of triacylglycerols has an impact on their molar mass, density, melting point, solubility, a fact that has a direct influence on the stability of oils against oxidative rancidity. This stability allows the use of these oils in confectionery products due to the increased shelf life of products without trans fatty acids (Jeyarani et al., 2009).

According to (Azeez 2007), the fatty acid profile of coconut oil can change depending on the season and the maturation of the nut, as well as the differences between the cultivars. Fatty acid rates can increase or decrease from small to medium cadence due to the maturity of the nut and the concentration of unsaturated fatty acids (Ferreira et al., 2019).

\subsection{Nutritional Aspects}

Closer attention has been paid to the role of fats and oils in modern diet in recent decades due to their high caloric contribution to the diet itself and to health issues associated with the growing concern about obesity. However, studies show that some specific saturated fatty acids account for a wide spectrum of critical functions in physiological activities, depending on the unsaturation length and degree of the hydrocarbon chains. Fatty acids are not only essential nutrients, but they can also modulate many human diseases and conditions (Legrand \& Rioux, 2015; H. Lu et al., 2020).

\subsubsection{Absorption of medium-chain triglycerides}

Lipid catabolism coordinates lipolysis, which is the hydrolysis of triacylglycerides into free fatty acids, which account for the peroxisomal and mitochondrial $\beta$-oxidation of fatty acids to produce chemical energy (ATP) and heat (Rial et al., 2020).

The digestive bioavailability of medium-chain triacylglycerides (MCT) is greater than that of lon-chain triacylglycerides (LCT). The comparison between MCT and LCT has shown that MCT hydrolysis, which starts in the stomach, is faster and more complete than that of LCT, as well as its gastrointestinal transit speed is faster and its absorption occurs in the proximal portion of the small intestine, a fact that makes it faster and more efficient (Ferreira et al., 2003).

Fatty acids undergo different metabolic pathways depending on their saturation degree and on chain length. Mediumchain saturated fatty acids (carbon chains presenting up to 12 carbons) can be transported right to the mitochondria without the aid of membrane transporters. They are promptly absorbed by the enterocytes and transported directly to the liver by the blood in order to produce energy. On the other hand, long-chain fatty acids travel through the lymphatic system via chylomicrons to extrahepatic tissues where they can be stored in the form of triglycerides (Heil et al., 2019).

The transport of lipids in the body is overall described in the exogenous and endogenous metabolic pathways. The exogenous pathway represents the transport of dietary lipids from the intestine to the liver. The endogenous pathway describes the transport of lipoproteins synthesized in hepatocytes from the liver to peripheral tissues. Medium-chain fatty acids are easily transported in the plasma since they bind to albumin during the post-absorptive phase; they also take the portal vein and quickly reach the liver (Montgomery et al., 2019).

Approximately $80 \%$ to $100 \%$ of medium-chain fatty acid (MCFA) found in the entire portal flow are captured by the liver and the remaining portion of them flows through the bloodstream and becomes available to peripheral tissues (Ronis et al., 2013; X. Lu, Chen, et al., 2019a). MCFAs are partially converted into ketone bodies and released into the blood due to fast metabolism of MCT in the liver. Approximately $10 \%$ of ingested MCFAs are detected as chylomicrons in postprandial venous blood (Ronis et al., 2013; Wang et al., 2016) and it turns medium-chain fatty acids into a fast source of energy (Yoshihara et 
al., 2020).

The high intake of medium-chain fatty acids rich in triglycerides leads to the significant intracellular incorporation of them into chylomicrons (in the resynthesized triacylglycerol form). This incorporation likely depends on the consumed amount and distribution of medium-chain fatty acids in the ingested triacylglycerides (Heil et al., 2019).

\subsubsection{Medium-chain fatty acid in lipid oxidation}

Mitochondria are important sites for lipid oxidation. Several mitochondrial metabolism markers are used to determine whether intracellular lipid levels can be related to differences in fatty acids size of the chain. Diets high in fat and MCFAs increase mitochondrial biogenesis in skeletal muscle (Ishizawa et al., 2015; Montgomery et al., 2019). In addition to the postprandial absorption pathway, MCFA effects on muscle mitochondrial biogenesis are affected by metabolic degradation of the liver (Thevenet et al., 2016). MCFAs induce much greater increase in the activity of the muscle oxidative enzyme (Montgomery et al., 2019) (Thevenet et al., 2016). A study carried out with sedentary individuals in the age group 40 and 60 years who received a diet rich in medium-chain fatty acids showed that exercising increases and improves the aerobic capacity in terms of oxygen transport and cardiac output capacity (Nosaka et al., 2020).

High fat-based MCFA diet increases the activity of the Citrate Synthase (CS) mitochondrial oxidative enzyme in both fast and slow skeletal muscle contractions (Ishizawa et al. 2015). However, based on the current results, MCFA-based diets increased the activity of the mitochondrial oxidative enzyme in slow muscle contraction. The ability of the muscle to increase mitochondrial concentration, density and oxidative enzymatic activity (e.g., CS activity) is an important muscle adaptation to resistance exercises. Oxidative enzyme activity, in its turn, is associated with significant mitochondrial biogenesis simulation (Ströher et al., 2020).

\subsubsection{Medium-chain fatty acid in obesity control}

Some studies have suggested that medium chain fatty acids are potential obesity control factors (Assunção et al., 2009; Zhou et al., 2017). Studies with humans and rodents have shown that MCFA induces higher energy expenditure than LCFA, but such an outcome has also been associated with lower adipose tissue accumulation (Ishizawa et al., 2015).

A study carried out with rats fed on diet rich in MCFA has evidenced that rats' body weight was lower when they fed on diet rich in MCFA than that of rats who did not. Rats who fed on long-chain fatty acids (LCFA), even at equal energy value, have shown that diets rich in MCFA can reduce fat accumulation. Plasma glucose concentrations were significantly higher in the LCFA group than in the MCFA group (Ishizawa et al., 2015; Turner et al., 2009). Such features are indicative that MCFA can be recommended as dietary supplement to prevent obesity and high fat diet-related diseases.

\subsubsection{Medium-chain fatty acid for diabetes control}

Resistance to insulin is defined as the reduced ability of insulin to regulate the metabolism of carbohydrates and lipids in target tissues. It is one of the main metabolic obesity and type 2 diabetes issues.

Diets rich in MCFA reduce plasma glucose levels and improve insulin sensitivity in comparison to diets rich in LCFA (Ferreira et al., 2019; Turner et al., 2009). A study based on coconut oil addition to the diet showed increased fatty acids and triglycerides availability, and it may have changed glucose using in oxidative mitochondrial metabolism (Yoshihara et al., 2020), since metabolic changes related to glucose metabolism and resistance to insulin are closely associated with increased dietary fat intake.

Progressive resistance to insulin and the subsequent hyperglycaemia caused by high-fructose intake diet leads to 
symptoms similar to those of hepatic steatosis, in rats (De Moura et al., 2008). Coconut oil supplementation reversed the hepatic steatosis condition in addition to having better resistance to insulin, lower glucose levels, higher HDLc levels and lower levels of total cholesterol and triacylglycerols. These outcomes are attributed to improvement in the hepatic steatosisassociated dyslipidemic condition (Narayanankutty et al., 2018).

Other studies have reported that diets rich in coconut oil have hypolipidemic activity mediated by its effect on lipid metabolism; they also have antidiabetic activity in diabetic models due to high fructose and fast MCFA absorption and metabolism. Narayanankutty et al. (2018) observed that diets rich in coconut oil have shown that MCFA improves fat's beta oxidation and protects individuals from liver disease caused by excess of fat (Ronis et al.,2013). MCFA markedly decreased the percentage of apoptotic and late cells necrosis in comparison to the long-chain fatty acid. Moreover, it did not induce apoptosis, oxidative stress and chronic inflammatory responses in liver cells of individuals with steatosis. (Wang et al.,2016).

\subsubsection{Medium-chain fatty acid to control cardiovascular diseases}

Postprandial triglycerides (TG) are among factors accounting for the development of cardiovascular diseases (Jackson et al.,2012). TG levels reflect the presence of remaining lipoproteins that can cause atherosclerosis (Austin et al., 2020). MCFA reduced postprandial TG levels since it was transported through portal circulation and was little incorporated to chylomicrons. MCAF fast beta oxidation in the liver results in decreased TG synthesis (Jackson et al., 2012). There was significant reduction in serum TG levels due to MCFA diet intake in comparison to the LCFA diet.

The MCFA diet did not affect the total levels of free fatty acids. Postprandial hypertriglyceridemia appeared to be related to fasting atherogenic dyslipidaemia, increased stress oxidation and impaired haemostasis. All together, these factors can contribute to impair the vascular function and to the development of atherosclerotic cardiovascular disease. Thus, MCFA oil consumption can limit the entry of circulating chylomicron-TG and, consequently, reduce the residence time of remaining lipoproteins rich in atherogenic TG (Lee et al., 2019). However, the study by Austin et al. (2020) did not demonstrate any beneficial effect of MCFA-rich diets on postprandial TG reduction. These effects were only observed when MCFA was combined to fish oil.

The Table 2 shows clinical studies in vivo and in vitro on the use of triglycerides in the diet. Featuring type of used oil, dosage administered and observed benefits. 
Table 2: Physiological effects of dietary MCFA / MCT observed in clinical studies.

\begin{tabular}{|c|c|c|c|c|c|}
\hline Assessed Component & Declared Composition & Dosage/ period & Assessed Individual & Observed Effect & Reference \\
\hline MCFA & C8:0- C18:3 & $\begin{array}{l}45 \% \text { to } 60 \% \text { calories of } \\
\text { diet } / 21 \text { days }\end{array}$ & Mice & $\begin{array}{l}\text { Adiposity reduction and glucose } \\
\text { intolerance improvement. }\end{array}$ & Turner et al.,2009 \\
\hline MCFA & MCFA-rich oil & $\begin{array}{l}60 \% \text { of calories of diet/ } 4 \\
\text { weeks }\end{array}$ & 5-week-old male Wistar rats & $\begin{array}{l}\text { Increases the activity of the } \\
\text { mitochondrial oxidative enzyme }\end{array}$ & Ishizawa et al.,2015 \\
\hline MCFA & C8:0- C18:3 & $\begin{array}{l}45 \% \text { of calories of diet/ } 8 \\
\text { weeks }\end{array}$ & $\begin{array}{l}\text { Mice (absence of Gpr84 } \\
\text { protein) }\end{array}$ & $\begin{array}{l}\text { Mitochondrial regulation, insulin } \\
\text { response }\end{array}$ & Montgomery et al., 2019 \\
\hline MCT & $\begin{array}{c}\text { Nestle Nutrition } \\
\text { (82\%MCT /18\% Bovine } \\
\text { tallow) }\end{array}$ & $\begin{array}{c}20 \%, 35 \%, 50 \%, 65 \% \text { for } \\
21 \text { days }\end{array}$ & Male rats & Metabolic syndrome, hepatic steatosis & Ronis et al., 2013 \\
\hline MCT & FA C8:0 & 12 months & Mice & $\begin{array}{l}\text { Treatment for Acil -CoA } \\
\text { dehydrogenase deficiency }\end{array}$ & Tucci et al., 2015 \\
\hline MCT & FA C8:0, C10:0 & $10 \%, 20 \%, 30 \% \mathrm{p} / \mathrm{p}$ & Mice & Obesity control, body weight reduction & Zhou et al., 2017 \\
\hline MCT & 40:60 ratio of MCT C8:10 & $5 \%$ of diet & Wistar rats & Social behaviour & Hollis et al., 2018 \\
\hline MCT & $\begin{array}{l}\text { C8:0, C10:0-Nestlé } \\
\text { Switzerland }\end{array}$ & $30 \mathrm{~g} / 2.000 \mathrm{kcal}$ & $\begin{array}{l}18-65 \text { year old individuals } \\
\mathrm{BMI} \leq 5.0 \mathrm{~kg} / \mathrm{m}^{2}\end{array}$ & Glucose and insulin metabolism & Thomas et al., 2019 \\
\hline MCT & FA C8:0, C10:00 & $6 \mathrm{~g} /$ day & $\begin{array}{l}\text { 40-60 year old sedentary } \\
\text { individuals }\end{array}$ & $\begin{array}{l}\text { Increased aerobic capacity, oxygen } \\
\text { transport and cardiac output capacity }\end{array}$ & Nosaka et al., 2020 \\
\hline $\mathrm{MCT}$ & $\begin{array}{c}\text { Dermol M-5 } \\
\text { (ALZO international ) }\end{array}$ & $\begin{array}{c}45 \mathrm{kcal}(40 \% \mathrm{MCT}- \\
60 \% \mathrm{C}: 8 \text { and C:10/ } 5 \% \\
\text { TCL-Soy) }\end{array}$ & Mice & Hepatic thermogenesis & Rial et al., 2020 \\
\hline Coconut oil & Virgin commercialisation & $\begin{array}{l}5 \% \text { and } 15 \% \text { of basal diet- } \\
10 \text { days }\end{array}$ & Wistar rats & Antioxidant and hepatoprotective & Famurewa et al., 2017 \\
\hline
\end{tabular}


Research, Society and Development, v. 10, n. 7, e43710716667, 2021

(CC BY 4.0) | ISSN 2525-3409 | DOI: http://dx.doi.org/10.33448/rsd-v10i7.16667

\begin{tabular}{|c|c|c|c|c|c|}
\hline Coconut oil & $\begin{array}{c}\text { Santa Cruz } \\
\text { Biotechnology, TX, USA }\end{array}$ & $4.5 \mathrm{~g} / \mathrm{Kg}-180$ days & Wistar rats & Hypertrophy & Quitete et al., 2019 \\
\hline Coconut oil & Organic commercialisation & 1.3 and $9 \mathrm{~g} / \mathrm{kg}-12$ weeks & Mice & $\begin{array}{l}\text { Inflammatory and metabolic } \\
\text { dysfunction }\end{array}$ & Zicker et al.,2019 \\
\hline Coconut oil & Virgin & $2 \mathrm{ml} / \mathrm{kg}-30$ days & Rats & $\begin{array}{l}\text { Metabolic changes due to lipid } \\
\text { accumulation in the liver }\end{array}$ & Ströher et al., 2020 \\
\hline
\end{tabular}

Wherein: MCFA: medium chain fatty acid, MCT: medium chain triacylglycerol, FA: fatty acid. Source: Authors. 
Table 2 shows some in vivo and in vitro clinical studies about MCFAs use in diet and its benefits. From these studies was highlighted the type of MCFAs applicated, whether it was pure or associated with other oils, and its necessary period of use. Studies show a range of benefits associated with MCFAs use, better insulin response, better obesity control, better arterial blood pressure, being used isolated or mixed in high concentration in oil.

\subsection{Technological Aspects}

The concern of consumers to have a healthier life shows the search for products with less fats, mainly of animal origin (Kiliç \& Özer 2019). In order to meet consumer demands, there is a growing interest in studying vegetable oils to partially or totally replace animal fat in order to improve the textural quality, appearance and oxidation stability of products (Goibier et al., 2020; Nguyen et al., 2021)

\subsubsection{Application of the MCFA in food formulations}

Bhatnagar et al., (2009) tested blends of vegetable oils such as flaxseed, rice, sunflower and soy added with coconut oil. They evaluated the oxidative stability of mixes and observed that blends with coconut oil showed greater oxidative stability because it is less likely to form peroxide due to the presence of medium chains.

Coconut oil was also used by Szafrańska (2020) in cheese sauce formulations to replace anhydrous milk fat. Visually the sauces with milk fat and the sauce with coconut oil showed differences, however the technological characteristics such as stability, viscosity, water activity of the coconut oil made it a good alternative for the production of analogues to the cheese sauce (Szafrańska et al., 2020).

Ali (2020) showed used coconut oil in vegetable meat formulations as ingredient added to unsaturated oil in order to add texture and sensory aspect similar to that of beef. Saturated and unsaturated oils are mixed to form white dots in hamburgers and vegetable sausages, and to simulate animal fat (Chatterjee et al., 2020; Guimarães et al., 2007).

Kiliç et al. (2019) assessed animal fat replacement by kernel palm oil in sausages, which showed excellent sensory results and no significant differences between treatments focused on colour, odour, flavour, juiciness, texture and general acceptance. Kiliç et al. (2017) also assessed animal fat replacement by kernel palm oil in sausage and found that bovine fat replacement by kernel palm oil can be a strategy to improve nutritional quality without having negative effect on quality features. In addition, meat fat replacement by kernel palm oil has not significantly contributed to lipid oxidation development (Kiliç \& Özer 2017, 2019).

Goibier (2020) used triacylglycerides that crystallize at $20^{\circ} \mathrm{C}$, such as coconut oil, as a stabilizer for a double (W1 / O / W2) emulsion. Emulsions are complex liquid dispersions of oil globules containing small aqueous droplets. These systems have great potential to arrest and control the release of aroma and flavor in the field of food production, to protect and arrest probiotics, to mask flavor and to reduce the fat content in foods. Initially obtained emulsions were relatively fluid, but after a few hours at $20^{\circ} \mathrm{C}$, they presented considerable yield, strength and firmness. As crystallization proceeded, solid bridges formed between aggregated crystals that further strengthened the network. The W/O emulsion obtained was stabilized only by triglycerides; it did not demand the addition of surfactants, resisted osmotic shocks and was not subjected to coalescence under storage conditions, at room temperature (Goibier et al., 2020).

\subsubsection{Stability of oil-in-water emulsion systems}

Most industrialized foods are oil-in-water emulsions, such as beverages, sauces and ice cream, and are also used in the pharmaceutical, cosmetic and oil industries. Naturally, this system does not remain stable, making them dependent on the use 
of emulsifiers (H. Lu et al., 2020).

Many emulsions based on coconut oil and water as vegetable drinks are being introduced to the market, it is necessary that this emulsion remains stable. Emulsification is characterized by the dispersion of immiscible liquid in other liquids based on the use of high shear energy. Requires the use of an emulsifying agent to avoid separation of the subsequent phase (Ramisetty et al., 2015). In addition to the type of emulsifier, the mixing method, pressure of homogenization influences the stability of the emulsion, as shown in table 3 .

In general, the mixing process is one of the most important unit operations that influence the size of the drops and the stability of the emulsion. Studies have already shown the effect of different homogenization pressures and their response to the stability of the emulsion (Cheng et al., 2020; Matsuura et al., 2015). Other types of processing have been used to prepare ultrasonic emulsions that have shown excellent results in reducing particle size and excellent morphologies: particles of uniform size that favor emulsions and, consequently, avoid coalescence (Gulão et al., 2018; X. Lu, Su, et al., 2019b; Ramisetty et al., 2015; Saricaoglu et al., 2018). The final average size of the drops and their distribution depend on the dissipation of energy, which, in turn, depends on the intensity of the cavitation (Lu et al., 2020).

Emulsifying agents are responsible for the development of bonds between two immiscible liquids, acting as a surfaceacting agent. The hydrophilic head of the emulsifying agent has a good connection with the aqueous phase and the lipophilic tail connects with the oil phase to bring these two liquids together. The lipophilic tips of the tail move towards the center of the oil drop and the hydrophilic layer goes to the emulsifying agent around the surface of the spherical oil droplets which prevent the oil droplets from coalescing and stabilize the emulsion. (Ramisetty et al., 2015). Therefore, using sufficient amount of emulsifying agent allows the emulsion to be made more stable for long periods of time (Table 3). 
Table 3: Coconut oil-in-water-type emulsions stabilized with different types of emulsifiers.

\begin{tabular}{|c|c|c|c|c|c|c|}
\hline Emulsifying agent & $\begin{array}{c}\text { Source of } \\
\text { emulsifying agent }\end{array}$ & $\begin{array}{l}\text { Emulsifier } \\
\text { dosage }\end{array}$ & $\begin{array}{l}\text { Formulation of the } \\
\text { assessed emulsion }\end{array}$ & $\begin{array}{l}\text { Mechanical process } \\
\text { applied to emulsion }\end{array}$ & $\begin{array}{c}\text { Effect observed in the } \\
\text { emulsion }\end{array}$ & Reference \\
\hline Lactoferrin & Bovine milk & $3 \% \mathrm{p} / \mathrm{v}$ & $\begin{array}{l}10 \% \text { coconut oil } / 90 \% \\
\text { water }\end{array}$ & $\begin{array}{l}\text { Ultrasound } 30 \\
\text { KHz/3min- } 25^{\circ}\end{array}$ & $\begin{array}{l}\text { Emulsion stability during 7- } \\
\text { day storage. }\end{array}$ & Gulão et al., 2018 \\
\hline $\begin{array}{l}\text { Albumin and } \\
\text { Globulin }\end{array}$ & Coconut pulp & $1 \% \mathrm{p} / \mathrm{p}$ & $1: 9$ coconut milk/ water & $\begin{array}{l}\text { Homogenizer } \\
3000 \text { psi- } 2 \mathrm{x}\end{array}$ & $\begin{array}{l}\text { The globulin fraction is more } \\
\text { effective in stabilizing the } \\
\text { emulsion. }\end{array}$ & Patil \& Benjakul, 2017 \\
\hline $\begin{array}{l}\text { Pre-gelatinized Rice } \\
\text { Starch }\end{array}$ & Rice & $5 \%$ to $7 \%$ & $10 \%$ coconut oil & $\begin{array}{c}\text { Ultra-Turrax at } 8.000, \\
11.000, \\
\text { and } 15.000 \mathrm{rpm} / \\
\text { Calorimetry } 30^{\circ} \mathrm{c} \text { and } \\
50^{\circ} \mathrm{C}\end{array}$ & $\begin{array}{l}\text { It showed better results in both } \\
\text { heating and stirring conditions } \\
\text { than the other oil. }\end{array}$ & $\begin{array}{c}\text { Yulianingsih \& Gohtani, } \\
2020\end{array}$ \\
\hline Egg yolk & Egg & $6 \% \mathrm{w} / \mathrm{w}$ & $\begin{array}{c}\text { Coconut oil + Palm oil } \\
\text { diaglycerol }(0 \%, 10 \%, \\
20 \%, 30 \%)\end{array}$ & $\begin{array}{l}\text { Agitator } \\
12.500 \mathrm{rpm} / 6 \mathrm{~min}\end{array}$ & $\begin{array}{l}\text { Samples with coconut oil alone } \\
\text { were more stable for } 30 \text { days. }\end{array}$ & $\mathrm{Ng}$ et $\mathrm{al}, .2014$ \\
\hline $\begin{array}{l}\text { Tween } 80 \text { and } \\
\text { Span } 80\end{array}$ & - & $\begin{array}{c}0.02,0.04 \\
0.05,0.07 \\
0.09,0.11 \text { and } \\
0.12 \mathrm{w} / \mathrm{w}\end{array}$ & $\begin{array}{l}0.1 \%, 0.2 \%, 0.3 \% \text { and } \\
0.4 \% \text { of coconut oil. }\end{array}$ & $\begin{array}{l}\text { Ultrasound Processor } \\
-20 \mathrm{KHz} \text { and } 750 \mathrm{~W} \\
-20 \mathrm{KHz} 1500 \mathrm{~W} \\
-20 \mathrm{KHz} 1000 \mathrm{~W}\end{array}$ & $\begin{array}{l}\text { The greater the power of the } \\
\text { processor, the smaller the size } \\
\text { of fat droplets, the better the } \\
\text { stability of the emulsion. }\end{array}$ & Ramisetty et al., 2015 \\
\hline WPC $80 \%$ & Whey & $\begin{array}{c}2 \%, 3 \%, 4 \% \\
5 \%, 6 \%, 7 \%, 8 \\
\%\end{array}$ & $\begin{array}{l}10 \% \text { Anhydrous milk fat } \\
10 \% \text { milk and coconut oil }\end{array}$ & $\begin{array}{c}\text { Agitator } \\
10.000 \mathrm{rpm} / 2 \mathrm{~min} 80^{\circ} \mathrm{C}\end{array}$ & $\begin{array}{l}\text { Both are efficient in producing } \\
\text { cheese sauce. }\end{array}$ & Szafrańska et al., 2020 \\
\hline Sucrose esters (SE) & Sucrose & $\begin{array}{l}0.25 \% \text { in oil } \\
\text { weight }\end{array}$ & $5 \%$ oil in coconut milk & $\begin{array}{c}\text { Agitator } \\
\text { 11.200rpm / } 3 \mathrm{~min}\end{array}$ & $\begin{array}{l}\text { Emulsions with sucrose esters } \\
\text { were thermally more stable } \\
\text { than emulsions with Tween } 60 \text {. }\end{array}$ & Ariyaprakai et al., 2013 \\
\hline $\begin{array}{c}\text { Glyceryl } \\
\text { monostearate (GME) }\end{array}$ & Fat & $0-0.40 \%$ & $\begin{array}{c}10 \% \text { coconut oil } \\
4 \% \text { protein } \\
14 \% \text { sucrose } \\
0.25 \% \\
\text { carboxymethylcellulose }\end{array}$ & $\begin{array}{l}\text { Pasteurization } 65^{\circ} \\
\text { Homogenizer of } 2 \\
\text { pistons } 20 \mathrm{Mpa} \text { in the } \\
\text { first stage and } 4 \mathrm{Mpa} \text { in } \\
\text { the second stage. }\end{array}$ & $\begin{array}{c}\text { GME reduced fat cell } \\
\text { deformation and inhibited } \\
\text { partial coalescence }\end{array}$ & Cheng et al., 2020 \\
\hline
\end{tabular}


Research, Society and Development, v. 10, n. 7, e43710716667, 2021

(CC BY 4.0) | ISSN 2525-3409 | DOI: http://dx.doi.org/10.33448/rsd-v10i7.16667

\begin{tabular}{|c|c|c|c|c|c|c|}
\hline $\begin{array}{l}\text { Corn grain and } \\
\text { starch with different } \\
\text { amylose levels }\end{array}$ & Corn & 0.3 to $0.5 \mathrm{~g} / \mathrm{L}$ & $\begin{array}{c}6 \% \text { Coconut cream } \\
\text { (30.8\% fat, } 3.9 \text { protein) }\end{array}$ & $\begin{array}{c}\text { Mixer 13,500rpm / } 3 \\
\text { minutes - sterilization } \\
\text { after filling } 115^{\circ} \mathrm{C} / 20 \\
\text { min }\end{array}$ & $\begin{array}{l}\text { The higher the amylose } \\
\text { content, the higher the } \\
\text { viscosity and the better the } \\
\text { thermal stability. }\end{array}$ & M. Lu et al., 2020 \\
\hline $\begin{array}{c}\text { Glyceryl } \\
\text { monostearate (GME) } \\
\text { Waxy Starch }\end{array}$ & $\begin{array}{l}\text { Fat and } \\
\text { corn }\end{array}$ & 0.3 to $0.5 \mathrm{~g} / \mathrm{L}$ & $\begin{array}{l}6 \% \text { Coconut cream } \\
\text { (30.8\% fat, } 3.9 \text { protein) }\end{array}$ & $\begin{array}{l}\text { 20KHz high intensity } \\
\text { ultrasound }\end{array}$ & $\begin{array}{l}\text { Ultrasonic treatment resulted in } \\
\text { particle size reduction to } \\
\text { monomodal size distribution. }\end{array}$ & X. Lu, Chen, et al., 2019a \\
\hline $\begin{array}{l}\text { Dextrose (DE) and } \\
\text { Maltodextrose (MC) }\end{array}$ & - & $\begin{array}{c}27.5 \% \mathrm{p} / \mathrm{p}- \\
(2,10,25 \mathrm{DE})\end{array}$ & $20 \%$ w/w coconut oil & $\begin{array}{l}\text { High pressure } \\
\text { homogenizer - “ } 60 \mathrm{Mpa} \\
\text { in the } 1 \text { st stage and } \\
\text { 40Mpa in the } 2 \text { nd stage }\end{array}$ & $\begin{array}{l}\text { The best results were obtained } \\
\text { by using } 10 \% \text { dextrose } \\
\text { associated with sugar stearic } \\
\text { acid esters }\end{array}$ & Matsuura et al., 2015 \\
\hline
\end{tabular}

Wherein: w / v- weight / volume ratio, w / w: weight / weight ratio. Source: Authors. 
The substitution of animal fat for vegetable oils such as coconut oil and palm kernel oil in food products can present some difficulties because vegetable oils have different characteristics from animal fats and present differences in the homogenization of the mixture. Table 3 provides a compilation of scientific studies on the total or partial replacement of vegetable oils in food emulsions. Highlighting the type of emulsifier used, the dosage needed to stabilize the emulsions, the physical homogenization treatments, and the effects observed in the emulsion.

\section{Conclusion}

This review explored the technological and nutritional functions of vegetable oils that have medium-chain fatty acids in their composition. Fatty acids can be free or observed in their triacylglycerol form. They are intrinsically connected to the control of some diet-related diseases and to their technological applications in the food industry. Experimental studies have shown that dietary MCFA suppresses fat deposition through thermogenesis and fat oxidation both in animals and humans. In addition, several reports have suggested that MCFA has the therapeutic advantage of preserving insulin sensitivity in type 2 diabetes' animal and human models. MCTs enable technological benefits for the food industry, since they provide texture and flavour to products.

Further long-term studies are needed to test the cumulative effects of MCFA as a source of dietary lipids. Long-term tests can clarify whether continued use of MCFA maintains the nutritional benefits found and whether they are viable, comparing to daily consumption of other triglycerides such as long-chain fatty acids or unsaturated fatty acids.

\section{Acknowledgments}

Authors thank CNPq/VidaVeg LDTA, Capes (001) and FAPEMIG.

\section{References}

Ali, A. H., Wei, W., \& Wang, X. (2020). Characterisation of bovine and buffalo anhydrous milk fat fractions along with infant formulas fat: Application of differential scanning calorimetry, Fourier transform infrared spectroscopy, and colour attributes. LWT, 129,109542. https://doi.org/10.1016/j.1wt.2020.109542

Ariyaprakai, S., Limpachoti, T., \& Pradipasena, P. (2013). Interfacial and emulsifying properties of sucrose ester in coconut milk emulsions in comparison with Tween. Food Hydrocolloids, 30(1), 358-367. https://doi.org/10.1016/j.foodhyd.2012.06.003

Assunção, M. L., Ferreira, H. S., Dos Santos, A. F., Cabral, C. R., \& Florêncio, T. M. M. T. (2009). Effects of dietary coconut oil on the biochemical and anthropometric profiles of women presenting abdominal obesity. Lipids, 44(7), 593-601. https://doi.org/10.1007/s11745-009-3306-6

Austin, G., Ferguson, J. J., Thota, R. N., Singh, H., Burrows, T., \& Garg, M. L. (2020). Postprandial lipaemia following consumption of a meal enriched with medium chain saturated and/or long chain omega-3 polyunsaturated fatty acids. A randomised cross-over study. Clinical Nutrition, July, 1-8. https://doi.org/10.1016/j.clnu.2020.06.027

Bhatnagar, A. S., Prasanth Kumar, P. K., Hemavathy, J., \& Gopala Krishna, A. G. (2009). Fatty acid composition, oxidative stability, and radical scavenging activity of vegetable oil blends with coconut oil. JAOCS, Journal of the American Oil Chemists' Society, 86(10), 991-999. https://doi.org/10.1007/s11746$009-1435-\mathrm{y}$

Chatterjee, P., Fernando, M., Fernando, B., Dias, C. B., Shah, T., Silva, R., Williams, S., Pedrini, S., Hillebrandt, H., Goozee, K., Barin, E., Sohrabi, H. R., Garg, M., Cunnane, S., \& Martins, R. N. (2020). Potential of coconut oil and medium chain triglycerides in the prevention and treatment of Alzheimer's disease. Mechanisms of Ageing and Development, 186, 111209. https://doi.org/10.1016/j.mad.2020.111209

Cheng, J., Dudu, O. E., Wang, D., Li, X., \& Yan, T. (2020). Influence of interfacial adsorption of glyceryl monostearate and proteins on fat crystallization behavior and stability of whipped-frozen emulsions. Food Chemistry, 310, 125949. https://doi.org/10.1016/j.foodchem.2019.125949

Costa, W. A. da, Bezerra, F. W. F., Oliveira, M. S. de, Andrade, E. H. de A., Santos, A. P. M. dos, Cunha, V. M. B., Santos, D. C. S. dos Banna, D. A. D. da S., Teixeira, E., \& Carvalho Junior, R. N. de. (2019). Supercritical CO 2 extraction and transesterification of the residual oil from industrial palm kernel cake with supercritical methanol. Journal of Supercritical Fluids, 147, 179-187. https://doi.org/10.1016/j.supflu.2018.10.012

D’Anton Reipert, É. C., Rodrigues, C. E. C., \& Meirelles, A. J. A. (2011). Phase equilibria study of systems composed of refined babassu oil, lauric acid, ethanol, and water at 303.2 K. Journal of Chemical Thermodynamics, 43(12), 1784-1790. https://doi.org/10.1016/j.jct.2011.05.039 
De Moura, R. F., Cambri, L. T., De Quadros, A. C., Nascimento, C. M. C., Arantes, L. M., Sebastião, E., Tanaka, K., Papini, C. B., Oliani, M. M., Mota, C. S D. A., Ribeiro, C., \& Melo, M. A. R. (2008). Capacidade aeróbia de ratos alimentados com dieta rica em frutose. Revista Brasileira de Medicina Do Esporte, 14(5), 422-426. https://doi.org/10.1590/S1517-86922008000500004

de Oliveira, N. A., dos Santos Garcia, A. B., Mazalli, M. R., Fukumasu, H., \& de Oliveira, A. L. (2019). Babassu almonds oil extracted with alternative pressurized green solvents, its triacylglycerol prediction and $\beta$-sitosterol composition. Journal of Food Process Engineering, 42(5), 1-9. https://doi.org/10.1111/jfpe.13139

De Pinho, A. P. S., \& Souza, A. F. (2018). Extração e caracterização do óleo de coco (Cocos nucifera L.). Biológicas \& Saúde, 8(26), 9-18. https://doi.org/10.25242/886882620181241

Dhamodharan, P., \& Bakthavatsalam, A. K. (2020). Experimental investigation on thermophysical properties of coconut oil and lauryl alcohol for energy recovery from cold condensate. Journal of Energy Storage, 31(May), 101639. https://doi.org/10.1016/j.est.2020.101639

Famurewa, A. C., Ufebe, O. G., Egedigwe, C. A., Nwankwo, O. E., \& Obaje, G. S. (2017). Virgin coconut oil supplementation attenuates acute chemotherapy hepatotoxicity induced by anticancer drug methotrexate via inhibition of oxidative stress in rats. Biomedicine and Pharmacotherapy,87, 437-442. https://doi.org/10.1016/j.biopha.2016.12.123

Ferrari, R. A., \& Soler, M. P. (2015). Obtention and characterization of coconut babassu derivatives. Scientia Agricola, 72(4), 291-296. https://doi.org/10.1590/0103-9016-2014-0278

Ferreira, J. A., Santos, J. M., Breitkreitz, M. C., Ferreira, J. M. S., Lins, P. M. P., Farias, S. C., de Morais, D. R., Eberlin, M. N., \& Bottoli, C. B. G. (2019). Characterization of the lipid profile from coconut (Cocos nucifera L.) oil of different varieties by electrospray ionization mass spectrometry associated with principal component analysis and independent component analysis. Food Research International, 123(October 2018), 189-197. https://doi.org/10.1016/j.foodres.2019.04.052

Goibier, L., Pillement, C., Monteil, J., Faure, C., \& Leal-Calderon, F. (2020). Preparation of multiple water-in-oil-in-water emulsions without any added oilsoluble surfactant. Colloids and Surfaces A: Physicochemical and Engineering Aspects, 590(January), 124492. https://doi.org/10.1016/j.colsurfa.2020.124492

Guimarães, D. E. D., Sardinha, F. L. de C., Mizurini, D. de M., \& Carmo, M. das G. T. do. (2007). Adipocitocinas: uma nova visão do tecido adiposo. Revista de Nutrição, 20(5), 549-559. https://doi.org/10.1590/s1415-52732007000500010

Gulão, S., Junior, C., Souza, F. De, Ribeiro, A., Helena, M., \& Garcia-rojas, E. E. (2018). Stability and rheological behavior of coconut oil-in-water emulsions formed by biopolymers. Polímeros, 28(5), 413-421. https://doi.org/10.1590/0104-1428.08017

Heil, C. S., Wehrheim, S. S., Paithankar, K. S., \& Grininger, M. (2019). Fatty Acid Biosynthesis: Chain-Length Regulation and Control. ChemBioChem, 20(18), 2298-2321. https://doi.org/10.1002/cbic.201800809

Hollis, F., Mitchell, E. S., Canto, C., Wang, D., \& Sandi, C. (2018). Medium chain triglyceride diet reduces anxiety-like behaviors and enhances social competitiveness in rats. Neuropharmacology, 138, 245-256. https://doi.org/10.1016/j.neuropharm.2018.06.017

Ishizawa, R., Masuda, K., Sakata, S., \& Nakatani, A. (2015). Effects of different fatty acid chain lengths on fatty acid oxidation-related protein expression levels in rat skeletal muscles. Journal of Oleo Science, 64(4), 415-421. https://doi.org/10.5650/jos.ess14199

Jackson, K. G., Poppitt, S. D., \& Minihane, A. M. (2012). Postprandial lipemia and cardiovascular disease risk: Interrelationships between dietary, physiological and genetic determinants. Atherosclerosis, 220(1), 22-33. https://doi.org/10.1016/j.atherosclerosis.2011.08.012

Jeyarani, T., Imtiyaj Khan, M., \& Khatoon, S. (2009). Trans-free plastic shortenings from coconut stearin and palm stearin blends. Food Chemistry, 114(1), 270-275. https://doi.org/10.1016/j.foodchem.2008.09.052

K1lıç, B., \& Özer, C. O. (2019). Potential use of interesterified palm kernel oil to replace animal fat in frankfurters. Meat Science, 148), 206-212. https://doi.org/10.1016/j.meatsci.2018.08.024

Kumar, P. K. P., \& Krishna, A. G. G. (2015). Physicochemical characteristics of commercial coconut oils produced in India. Grasas y Aceites, 66(1). https://doi.org/10.3989/gya.0228141

Lee, A., Yoo, H. J., Kim, M., Kim, M., Choi, J. H., Lee, C., \& Lee, J. H. (2019). Effects of equivalent medium-chain diacylglycerol or long-chain triacylglycerol oil intake via muffins on postprandial triglycerides and plasma fatty acids levels. Journal of Functional Foods, 53, 299-305. https://doi.org/10.1016/j.jff.2018.12.021

Legrand, P., \& Rioux, V. (2015). Specific roles of saturated fatty acids: Beyond epidemiological data. European Journal of Lipid Science and Technology, 117(10), 1489-1499. https://doi.org/10.1002/ejlt.201400514

Lu, H., Guo, T., Fan, Y., Deng, Z., Luo, T., \& Li, H. (2020). Effects of diacylglycerol and triacylglycerol from peanut oil and coconut oil on lipid metabolism in mice. Journal of Food Science, 85(6), 1907-1914. https://doi.org/10.1111/1750-3841.15159

Lu, M., Zhang, T., Jiang, Z., Guo, Y., Qiu, F., Liu, R., Zhang, L., Chang, M., Liu, R., Jin, Q., \& Wang, X. (2020). Physical properties and cellular antioxidant activity of vegetable oil emulsions with different chain lengths and saturation of triglycerides. LWTt, 121, 108948. https://doi.org/10.1016/j.1wt.2019.108948

Lu, X., Chen, J., Zheng, M., Guo, J., Qi, J., Chen, Y., Miao, S., \& Zheng, B. (2019a). Effect of high-intensity ultrasound irradiation on the stability and structural features of coconut-grain milk composite systems utilizing maize kernels and starch with different amylose contents. Ultrasonics Sonochemistry, 55(February), 135-148. https://doi.org/10.1016/j.ultsonch.2019.03.003 
Lu, X., Su, H., Guo, J., Tu, J., Lei, Y., Zeng, S., Chen, Y., Miao, S., \& Zheng, B. (2019b). Rheological properties and structural features of coconut milk emulsions stabilized with maize kernels and starch. Food Hydrocolloids, 96(May), 385-395. https://doi.org/10.1016/j.foodhyd.2019.05.027

Marina, A. M., Che Man, Y. B., Nazimah, S. A. H., \& Amin, I. (2009). Chemical properties of virgin coconut oil. JAOCS, Journal of the American Oil Chemists' Society, 86(4), 301-307. https://doi.org/10.1007/s11746-009-1351-1

Matsuura, T., Ogawa, A., Tomabechi, M., Matsushita, R., Gohtani, S., Neoh, T. L., \& Yoshii, H. (2015). Effect of dextrose equivalent of maltodextrin on the stability of emulsified coconut-oil in spray-dried powder. Journal of Food Engineering, 163, 54-59. https://doi.org/10.1016/j.jfoodeng.2015.04.018

Montgomery, M. K., Osborne, B., Brandon, A. E., O’Reilly, L., Fiveash, C. E., Brown, S. H. J., Wilkins, B. P., Samsudeen, A., Yu, J., Devanapalli, B., Hertzog, A., Tolun, A. A., Kavanagh, T., Cooper, A. A., Mitchell, T. W., Biden, T. J., Smith, N. J., Cooney, G. J., \& Turner, N. (2019). Regulation of mitochondrial metabolism in murine skeletal muscle by the medium-chain fatty acid receptor Gpr84. FASEB Journal, 33(11), 12264-12276. https://doi.org/10.1096/fj.201900234

Narayanankutty, A., Palliyil, D. M., Kuruvilla, K., \& Raghavamenon, A. C. (2018). Virgin coconut oil reverses hepatic steatosis by restoring redox homeostasis and lipid metabolism in male Wistar rats. Journal of the Science of Food and Agriculture, 98(5), 1757-1764. https://doi.org/10.1002/jsfa.8650

Neves, M. I. L., Queirós, M. de S., Viriato, R. L. S., Ribeiro, A. P. B., \& Gigante, M. L. (2020). Physicochemical characteristics of anhydrous milk fat mixed with fully hydrogenated soybean oil. Food Research International, 132(January), 109038. https://doi.org/10.1016/j.foodres.2020.109038

Ng, S. P., Lai, O. M., Abas, F., Lim, H. K., \& Tan, C. P. (2014). Stability of a concentrated oil-in-water emulsion model prepared using palm olein-based diacylglycerol/virgin coconut oil blends: Effects of the rheological properties, droplet size distribution and microstructure. Food Research International, 64, 919-930. https://doi.org/10.1016/j.foodres.2014.08.045

Nguyen, V., Rimaux, T., Truong, V., Dewettinck, K., \& Van Bockstaele, F. (2021). The effect of cooling on crystallization and physico-chemical properties of puff pastry shortening made of palm oil and anhydrous milk fat blends. Journal of Food Engineering, 291 (May 2020 ), 110245. https://doi.org/10.1016/j.jfoodeng.2020.110245

Nik Norulaini, N. A., Setianto, W. B., Zaidul, I. S. M., Nawi, A. H., Azizi, C. Y. M., \& Omar, A. K. M. (2009). Effects of supercritical carbon dioxide extraction parameters on virgin coconut oil yield and medium-chain triglyceride content. Food Chemistry, 116(1), 193-197. https://doi.org/10.1016/j.foodchem.2009.02.030

Norizzah, A. R., Nur Azimah, K., \& Zaliha, O. (2018). Influence of enzymatic and chemical interesterification on crystallisation properties of refined, bleached and deodourised (RBD) palm oil and RBD palm kernel oil blends. Food Research International, 106(September 2017), 982-991. https://doi.org/10.1016/j.foodres.2018.02.001

Nosaka, N., Tsujino, S., Honda, K., Suemitsu, H., \& Kato, K. (2020). Enhancement of Fat Oxidation during Submaximal Exercise in Sedentary Persons: Variations by Medium-Chain Fatty Acid Composition and Age Group. Lipids, 55(2), 173-183. https://doi.org/10.1002/lipd.12222

Patil, U., \& Benjakul, S. (2017). Characteristics of albumin and globulin from coconut meat and their role in emulsion stability without and with proteolysis. Food Hydrocolloids, 69, 220-228. https://doi.org/10.1016/j.foodhyd.2017.02.006

Quitete, F. T., de Moura, E. G., Atella, G. C., Lisboa, P. C., \& de Oliveira, E. (2019). Differential effects in male adult rats of lifelong coconut oil exposure versus during early-life only. Journal of Functional Foods, 55(February), 17-27. https://doi.org/10.1016/j.jff.2019.02.020

Ramisetty, K. A., Pandit, A. B., \& Gogate, P. R. (2015). Ultrasound assisted preparation of emulsion of coconut oil in water: Understanding the effect of operating parameters and comparison of reactor designs. Chemical Engineering and Processing: Process Intensification, 88, $70-77$. https://doi.org/10.1016/j.cep.2014.12.006

Ratnayake, W. S., Hoover, R., Shahidi, F., Perera, C., \& Jane, J. (2001). Composition, molecular structure, and physicochemical properties of starches from four field pea (Pisum sativum L.) cultivars. Food Chemistry, 74(2), 189-202. https://doi.org/10.1016/S0308-8146(01)00124-8

Rennó, F. P., De Freitas Júnior, J. E., Gandra, J. R., Verdurico, L. C., Dos Santos, M. V., Barletta, R. V., Venturelli, B. C., \& Vilela, F. G. (2013). Fatty acid profile and composition of milk protein fraction in dairy cows fed long-chain unsaturated fatty acids during the transition period. Revista Brasileira de Zootecnia, 42(11), 813-823. https://doi.org/10.1590/S1516-35982013001100008

Rial, S. A., Jutras-Carignan, A., Bergeron, K. F., \& Mounier, C. (2020). A high-fat diet enriched in medium chain triglycerides triggers hepatic thermogenesis and improves metabolic health in lean and obese mice. Biochimica et Biophysica Acta - Molecular and Cell Biology of Lipids, 1865(3), 158582. https://doi.org/10.1016/j.bbalip.2019.158582

Rodrigues-Ract, J. N., Cotting, L. N., Poltronieri, T. P., da Silva, R. C., \& Gioielli, L. A. (2010). Comportamento de cristalização de lipídios estruturados obtidos a partir de gordura do leite e óleo de girasol. Ciencia e Tecnologia de Alimentos, 30(1), 258-267. https://doi.org/10.1590/s0101-20612010000100038

Ronis, M. J. J., Baumgardner, J. N., Sharma, N., Vantrease, J., Ferguson, M., Tong, Y., Wu, X., Cleves, M. A., \& Badger, T. M. (2013). Medium chain triglycerides dose-dependently prevent liver pathology in a rat model of non-alcoholic fatty liver disease. Experimental Biology and Medicine, 238(2), 151162. https://doi.org/10.1258/ebm.2012.012303

Sant'Anna Ramos Vosgerau, D., \& Paulin Romanowski, J. (2014). Estudos de revisão: implicações conceituais e metodológicas. Revista Diálogo Educacional, 14(41), 165. https://doi.org/10.7213/dialogo.educ.14.041.ds08

Santos, D. S., Da Silva, I. G., Araújo, B. Q., Júnior, C. A. L., Monção, N. B. N., Citó, A. M. D. G. L., De Souza, M. H. S. L., Nascimento, M. D. D. S. B., \& Costa, M. C. P. (2013). Extraction and evaluation of fatty acid compositon of orbignya phalerata martius oils (Arecaceae) from Maranhão state, Brazil. Journal of the Brazilian Chemical Society, 24(2), 355-362. https://doi.org/10.5935/0103-5053.20130045 
Saricaoglu, F. T., Gul, O., Besir, A., \& Atalar, I. (2018). Effect of high pressure homogenization (HPH) on functional and rheological properties of hazelnut meal proteins obtained from hazelnut oil industry by-products. Journal of Food Engineering, 233, 98-108. https://doi.org/10.1016/j.jfoodeng.2018.04.003

Soares, B. M. C., Gamarra, F. M. C., Paviani, L. C., Gonçalves, L. A. G., \& Cabral, F. A. (2007). Solubility of triacylglycerols in supercritical carbon dioxide. Journal of Supercritical Fluids, 43(1), 25-31. https://doi.org/10.1016/j.supflu.2007.03.013

Srivastava, Y., Semwal, A. D., \& Majumdar, A. (2016). Quantitative and qualitative analysis of bioactive components present in virgin coconut oil. Cogent Food \& Agriculture, 2(1) (1164929), 1-13. https://doi.org/10.1080/23311932.2016.1164929

Ströher, D. J., De Oliveira, M. F., Martinez-Oliveira, P., Pilar, B. C., Cattelan, M. D. P., Rodrigues, E., Bertolin, K., Gonçalves, P. B. D., Piccoli, J. D. C. E., \& Manfredini, V. (2020). Virgin Coconut Oil Associated with High-Fat Diet Induces Metabolic Dysfunctions, Adipose Inflammation, and Hepatic Lipid Accumulation. Journal of Medicinal Food, 23(7), 689-698. https://doi.org/10.1089/jmf.2019.0172

Szafrańska, J. O., Muszyński, S., \& Sołowiej, B. G. (2020). Effect of whey protein concentrate on physicochemical properties of acid casein processed cheese sauces obtained with coconut oil or anhydrous milk fat. LWT, 127, 109434 https://doi.org/10.1016/j.lwt.2020.109434

Thevenet, J., De Marchi, U., Domingo, J. S., Christinat, N., Bultot, L., Lefebvre, G., Sakamoto, K., Descombes, P., Masoodi, M., \& Wiederkehr, A. (2016). Medium-chain fatty acids inhibit mitochondrial metabolism in astrocytes promoting astrocyte-neuron lactate and ketone body shuttle systems. FASEB Journal, 30(5), 1913-1926. https://doi.org/10.1096/fj.201500182

Thomas, D. D., Stockman, M. C., Yu, L., Meshulam, T., McCarthy, A. C., Ionson, A., Burritt, N., Deeney, J., Cabral, H., Corkey, B., Istfan, N., \& Apovian, C. M. (2019). Effects of medium chain triglycerides supplementation on insulin sensitivity and beta cell function: A feasibility study. PLoS ONE, 14(12), 1-16. https://doi.org/10.1371/journal.pone.0226200

Tucci, S., Behringer, S., \& Spiekerkoetter, U. (2015). De novo fatty acid biosynthesis and elongation in very long-chain acyl-CoA dehydrogenase-deficient mice supplemented with odd or even medium-chain fatty acids. FEBS Journal, 282(21), 4242-4253. https://doi.org/10.1111/febs.13418

Turner, N., Hariharan, K., TidAng, J., Frangioudakis, G., Beale, S. M., Wright, L. E., Zeng, X. Y., Leslie, S. J., Li, J. Y., Kraegen, E. W., Cooney, G. J., \& Ye, J. M. (2009). Enhancement of muscle mitochondrial oxidative capacity and alterations in insulin action are lipid species dependent: Potent tissue-specific effects of medium-chain fatty acids. Diabetes, 58(11), 2547-2554. https://doi.org/10.2337/db09-0784

Wang, B., Li, L., Fu, J., Yu, P., Gong, D., Zeng, C., \& Zeng, Z. (2016). Effects of Long-Chain and Medium-Chain Fatty Acids on Apoptosis and Oxidative Stress in Human Liver Cells with Steatosis. Journal of Food Science, 81(3), H794-H800. https://doi.org/10.1111/1750-3841.13210

Yoshihara, H. A. I., Bastiaansen, J. A. M., Karlsson, M., Lerche, M. H., Comment, A., \& Schwitter, J. (2020). Detection of myocardial medium-chain fatty acid oxidation and tricarboxylic acid cycle activity with hyperpolarized [1-13C]octanoate. NMR in Biomedicine, 33(3), 1-8. https://doi.org/10.1002/nbm.4243

Yuhas, R., Pramuk, K., \& Lien, E. L. (2006). Human milk fatty acid composition from nine countries varies most in DHA. Lipids, 41(9), 851-858. https://doi.org/10.1007/s11745-006-5040-7

Yulianingsih, R., \& Gohtani, S. (2020). The influence of stirring speed and type of oil on the performance of pregelatinized waxy rice starch emulsifier in stabilizing oil-in-water emulsions. Journal of Food Engineering, 280(January), 109920. https://doi.org/10.1016/j.jfoodeng.2020.109920

Zhou, S., Wang, Y., Jiang, Y., Zhang, Z., Sun, X., \& Yu, L. L. (2017). Dietary Intake of Structured Lipids with Different Contents of Medium-Chain Fatty Acids on Obesity Prevention in C57BL/6J Mice. Journal of Food Science, 82(8), 1968-1977. https://doi.org/10.1111/1750-3841.13789

Zicker, M. C., Silveira, A. L. M., Lacerda, D. R., Rodrigues, D. F., Oliveira, C. T., de Souza Cordeiro, L. M., Lima, L. C. F., Santos, S. H. S., Teixeira, M. M., \& Ferreira, A. V. M. (2019). Virgin coconut oil is effective to treat metabolic and inflammatory dysfunction induced by high refined carbohydrate-containing diet in mice. In Journal of Nutritional Biochemistry (Vol. 63). https://doi.org/10.1016/j.jnutbio.2018.08.013 